\title{
Gauging the Relationship between Contextual Growth and Structural Neglect
}

${ }^{*}$ Dr. GALEN NEWMAN ${ }^{1}$,Dr. MICHELLE MEYER ${ }^{2}$, Dr. BOAH KIM ${ }^{3}$ and Dr. RYUN JUNG LEE ${ }^{4}$

1, 3, 4Department of Landscape Architecture and Urban Planning, Texas A\&M University, USA

2Department of Sociology, Lovisiana State University, USA

E MAIL: gnewman@arch.tamu.edu E mail:mmeyer@|su.edu ,E mail: boah.kim@gmail.com E mail: ryunjunglee@gmail.com

\begin{tabular}{|l|}
\hline A R T I C L E I N F O: \\
\hline Article history: \\
Received 10October 2017 \\
Accepted 16 August 2017 \\
Available online 16October \\
2017 \\
\hline Keywords: \\
Historic preservation; \\
Structural neglect; \\
Correlation; \\
Geographic \\
information systems; \\
Urban growth. \\
\hline
\end{tabular}

This work is licensed under a

Creative Commons Attribution

- NonCommercial- NoDerivs 4.0.

\begin{abstract}
A B S T R A C T
Population and land use out-migrations from urban to peripheral areas can result in non-functional, unmaintained historic structures which deteriorate to the point where removal is cheaper than removal - or demolition by neglect. The increasing rate of neglected historic structures is a growing concern. There is a need for research investigating connections between urban growth management and its effect on neglect. This paper applies Newman's (2013) conceptual model of measuring neglect to Geographic Information Systems, comparing rates of neglect in historic Doylestown, Quakertown, and Bristol boroughs in Pennsylvania, USA utilizing different amounts of peripheral agricultural preservation. Comparisons are made examining descriptive statistics on existing conditions, a Polychoric correlation evaluating relationships between drivers of neglect, and a crosscomparative GIS spatial analysis. Results indicate as amounts of peripheral preserved farmlands increase, neglect can be lowered.
\end{abstract}

JOURNAL OF CONTEMPORARY URBAN AFFAIRS (2018) 2(2), 33-45.

https://doi.org/10.25034/ijcua.2018.3669

www.ijcua.com

Copyright (c) 2017 Journal Of Contemporary Urban Affairs. All rights reserved.

\section{Urban Dynamics and Heritage Neglect}

Forrester (1969) theorizes that the city is a living organism whose form takes its shape as the result of a combination of external forces. Further, actions and interactions of cultures are a product of the desires, necessities, and values of a city's actors and give meaning to its form (Newman, 2015). This theory presupposes that comprehension of the built environment must be considered in conjunction with the understanding of both exogenous and endogenous factors and their causal relations(Ben-Hamouche, 2013).Listokin (1997) takes this theory a step further, positing that growth management and preservation of the built environment are fundamentally connected; he also states that these connections are, however, not fully understood. Local policies do not conserve built heritage fully (Pickerill \& Pickard, 2007). For example, evidence from historic areas in Germany has shown that contextual economic and political changes significantly impact historically preserved buildings (Alberts \& Brinda , 2005)

Historic preservation has a primary objective to protect structures and districts of historic prestige

*Corresponding Author:

Department of Landscape Architecture and Urban Planning, Texas A\&M University, USA

E-mail address: gnewman@ arch.tamu.edu 
from alteration, degradation, and demolition (Ben-Hamouche, 2013). Historic urban areas require high levels of support to retain structural viability, safeguard the integrity of heritage structures, and stimulate local economies. Urban spatial change is largely tied to alterations in contextual land uses, threatening many elements within the historic built environment. Simultaneously, many urban fringe areas (such as farmlands), the settings of historic urban buildings, are also threatened. As such, regulations now go beyond local preservation policies and include larger scaled contextual approaches for heritage management (Collins, Waters, \& Dotson, 1991). Centrifugal development has effected many urban historic buildings, in many cases resulting in their removal. Urban sprawl can create a uniform spatial form across cities and destroy much structural heritage in its wake (Treib, 2008; Yahner \& Nadenicek, 1997). Urban expansion can accelerate the loss of historic buildings because of a lack of utility, a process referred to as demolition by neglect (DBN). DBN is the removal of a historic building or structure due to prolonged vacancy and extreme maintenance issues (Leatherbarrow \& Mostafavi, 1993).

The capabilities of historic preservation policies to assist in retaining historic character and function in heritage buildings is highly dependent on the examination of process and changes within urbanized areas and their surrounding contexts (Alderson, 2006; Cook, 1996). Since urban contexts are constantly in flux, form and function rarely coincide in any environment for an extended period of time (Jackson, 1997). Contemporary historic preservation theory gives priority to form through the pursuit of historic integrity. An unfortunate outcome of this position is that if a historic building loses its function in contemporary society, it can also eventually be removed. Luckily, adaptive reuse and rehabilitation efforts have increased recently, leading to small upsurges in historic structure retainance in some localities (Newman, 2015).

Many U.S. historic structures are policed on a unitby-unit basis and are then analyzed based on whether or not they appear as they once did at a given historical time (or based on their historic integrity). Jigyasu (2002), notes that historic structures have two fundamental dimensions: historic integrity, and a relationship to the contextual environment with which they interact. A vital approach to the preservation of historic buildings lies with the ability to managing the individually with local policy (internally) and successful management of regional land use changes (externally). Therefore, the examination of the individual structure and its dynamic setting must occur if neglect can be fully understood. (Listokin, Listokin, \& Lahr, 1998; Pickerill \& Armitage, 2009).

The shift toward a more dynamic management of historic structures must focus on adaptive reuse, rehabilitation, and land use management. American historic preservation can differ from European approaches due to a stronger emphasis on local regulations in the U.S., while many European cities practice an area-based approach (Doratli, 2005). Area-based strategies can increase non-government funding, allow for greater expansions in historic districts, increase private sector investment in historic regeneration projects, and increase heritage rehabilitation in marginalized neighborhoods (Pickerill \& Armitage, 2009). In the U.S., broader heritage management approaches are typically regulatory or incentivebased. Regulatory measures, such as state regulated monetary penalties, generally involve punishment for allowing neglect to occur or continue. South Dakota statutes makes willful neglect a misdemeanor; in West Virginia, local landmark commissions enforce standards for the maintenance of landmarks; San Francisco, California can assess a $\$ 500$ per day penalty to owners who allow neglect to occur (National Trust for Historic Preservation, 2008).

Listokin (1997) theory suggests that local polices, when used in a singular approach, will not adequately result in conserved built heritage in the long-term(Alberts \& Brinda, 2005; Pickerill \& Pickard, 2007). Contemporary research reinforces this position, but shows a separation between historic preservation and external land use management (Avrami, 2012). Historic buildings are just one component within a larger, everchanging system; if both aims are focused to align to one goal, only then will the system be mutually beneficial properly (Newman \& Saginor, 
2014). Cassar (2009) suggests that historic preservation requires new research to aid in the understanding of how traditional buildings behave in environmental systems, if structural performance is to be improved.

Newman's (2013) conceptual model for measuring neglect takes a systems approach to measuring areas of the historic built environment. It is a method to begin to compare neglect rates across cities and historic districts to initialize the exploration of the effects of strategies for managing contextual growth and techniques to preserve the historic built environment. It is a framework for measuring neglect, based on Listokin's(1997) theory of urban dynamics. The model is a means to begin to examine area based approaches for regulating historic areas through the surveyance and analysis of neglect of the built environment, specifically in regards to historic buildings. Newman's model (2013) uses dimensions of integrity and viability from Listokin's (1997) theory to measure the rate of demolition by neglect. It is the only model currently utilized to measure this phenomenon. A synergetic relationship between urbanization and historic preservation can be eventually realized through increased application of the model. While the original model was developed and assessed through qualitative analysis, newer methods of analysis using Geographic Information Systems (GIS) should also be employed for more thorough spatial analyses.

\section{Geographic information Systems in Heritage Management}

GIS are powerful spatial tools using computational technologies which allow for storing altering, creating, displaying and overlaying spatial data (Limp, 1999). They offer the possibility to simultaneously store, organize, map and represent, manage, and analyze data concerning geographic locales and their context while. This allows for a much more thorough spatial analysis of an historic urban area (Burrough \& McDonnell, 1988). While information obtained from surveyance or research can be applied to generate new databases, the innovative tools involved with the program have been used too sparingly in historic built environment studies, typically involving analyses involving chronological historical spatial data combined with statistical assessments (Kvamme, 1993).

The field of archaeology, studying human activities of the past and their resultant material culture, has dominated the used of GIS in regards to historic preservation based research (Kaimaris, Sylaiou, Georgoula, \& Patias, 2011). While archaeologists globally have recognized the possibilities GIS can offer and applied its analytical tools in countries outside of America such as Scotland (Murray, 1995), France (Guillot \& Leroy, 1995) and Holland (Roorda \& Wiemer, 1992), preservationists applying GIS to solve the issues of current development patterns on neglected heritage structures are nearly nonexistent. Remote sensing applications, satellite imagery set the stage for initial historic structure analysis (Doneus, 2001) but as data sources have grown, new statistical analysis and multi-scalar analyst tools have been created to move beyond traditional GIS based approaches. Cultural resource management professionals have relied upon these databases for years to ensure the protection and preservation of valuable historic information (Box, 2003). GIS data can also be used as a way of distilling priorities for management decisions. For example, the Almería Province in Spain utilizes its cultural and heritage inventory data to assess the rehabilitation potential of buildings and has established a priority order for their reuse for a 'decision index' which corresponds to the considerations of each building (Cano, Garzon, \& Sanchez-Soto, 2013). This makes each management decision unique to its corresponding heritage structure.

In regards to the historic built environment, GIS have been primarily applied for landscape visualization, viewshed impact assessment, multiscale synthesis, spatial sampling, and forecast modelling. GIS must become more common in urban heritage studies to help synthesize efforts land use planning, environmental management and a variety of historic analyses; a new set of methods needs to be developed which may require preservationists to alter the way asses the historic built environment through expanding its scope beyond individual built units (Limp, 1999). 


\section{Research Questions and Methodology}

This research uses GIS to determine if contextual land use management helps deter neglect within the historic built environment. It seeks to answer the question, what relationship does farmland preservation have on neglect within historic urban areas? It is hypothesized that preserving fringe farmlands as a policy for external land use management can aid in increasing viable buildings within historic urbanized boroughs.

The urban boroughs analyzed - Bristol, Quakertown, and Doylestown - are all historic colonial cities in Bucks County, Pennsylvania, USA. Pennsylvania uses farmland preservation to aid in the conservation of the historic character of its boroughs and townships as a means of countering the effects of sprawl. Bucks County lost $70 \%$ of its agricultural properties from 19501997 (U.S. Department of Agriculture, 2005). The entire region was ranked second in the U.S when ranked according to areas with farmlands threatened to conversion (Olson \& Lyson, 1999) (Bourke, Jacob, \& Luloff, 1996). Bucks Count, is a contested landscape characterized by rapid land consumption and conversion. It is in southeast Pennsylvania within an area suffering from threatened farmland and concentrations of historic teardowns. From 1985 to 1995, Pennsylvania lost an area of farmland the size of Delaware to development while populations declined in many inner cities (Hylton, 1995). To counteract decentralization, the state enacted agricultural preservation as a primary means of managing growth

Table 1. Similarities of Cases under Investigation

\begin{tabular}{|c|c|c|c|}
\hline Variable & Doylestown & Quakertown & Bristol \\
\hline Population & 8227 & 8688 & 9923 \\
\hline Size & $2.2 \mathrm{~m} 2$ & $2.0 \mathrm{~m} 2$ & $1.9 \mathrm{~m} 2$ \\
\hline Date Founded & 1745 & 1803 & 1720 \\
\hline \# of Preserved Farms & 46 & 13 & 1 \\
\hline $\begin{array}{ll}\text { Total Acreage of } \\
\text { Preserved Farmland }\end{array}$ & 3323.38 & 1057.27 & 99.9 \\
\hline $\begin{array}{l}\text { Agricultural Preservation } \\
\text { Strategy }\end{array}$ & $\begin{array}{l}\text { Purchase of } \\
\text { Development Rights }\end{array}$ & $\begin{array}{l}\text { Purchase of } \\
\text { Development Rights }\end{array}$ & $\begin{array}{l}\text { Purchase of } \\
\text { Development Rights }\end{array}$ \\
\hline National Register Listing & Yes & Yes & Yes \\
\hline
\end{tabular}

Each borough under investigation is listed on the National Register of Historic Places (National Trust for Historic Preservation, 2008) and is approximately two-square-miles in size; similar polices for preserving farmlands are also practiced (purchase of development rights). Evaluating units of analysis within an identical county with analogous geographic sizes, populations, and ages helps to control for other intervening variables. We utilized the central place theory (King, 1984) to outline an external boundary for each borough to determine the highest impacted areas for the context according to town centers with this particular size and population (Table 1). Within this boundary, we calculated the total quantity of preserved agricultural lands which encircled each borough. Newman's model (2013) of calculating neglect is applied using (Figure 1) GIS based tools. It combines dimensions of integrity and viability using five factors: 1) timeframe of construction (when the building was built), 2) architectural modification (how much the building has been altered since construction), 3) land use change (how much the building's function has changed), 4) physical condition (the condition of each building), and 5) assessed value (the fair market value). A $95 \%$ confidence level was reached based on the sample size and clustered, multistage area random sampling was utilized to survey each building (Montello \& Sutton, 2006). Each factor was then measured by scoring three characteristics. 
The evaluation of conservation planning requires measurement on multiple scales for meaningful analysis (Nijkamp, 1991). The research utilized three scales of analysis: an inventory presenting descriptive statistics of the measures utilized to assess variables, a Polychoric correlation to assess relationships of variables, and GIS spatial analyses which combining geocoding, reclassification of attributes, Hot Spot Analysis, Inverse Distance Weighted (IDW) interpolation, Weighted Suitability overlays. The inventory describes conditions on a building by building scale; the correlation examined which variables impacted DBN significantly; and the comparison analyzed the relationship between DBN and amount of preserved agricultural lands. An ordinal scale was used in the inventory and GIS analyses to assign attributed to each building surveyed. Higher overall totals in summed scores indicated a lower occurrence of neglect. Characteristics accepted of each measure per variable were then evaluated using percentages as a means of inventorying conditions.

The scores for the five variables were then summed to evaluate structural neglect on a building scale. The total score of a given building could range from 5 to 15 . Neglected buildings had point ranges from 5 to 8 , transitory buildings had score ranges from 9 to 12 , and viable structures had scores ranging from 13 to 15. The relationship with each factor contributing to DBN neglect was assumed to be (as sums were greater, DBN was lessened), a Polychoric correlation was utilized to test correlation. The variables utilized to assess neglect were correlated with their overall impact in a specific location within the sample frame.

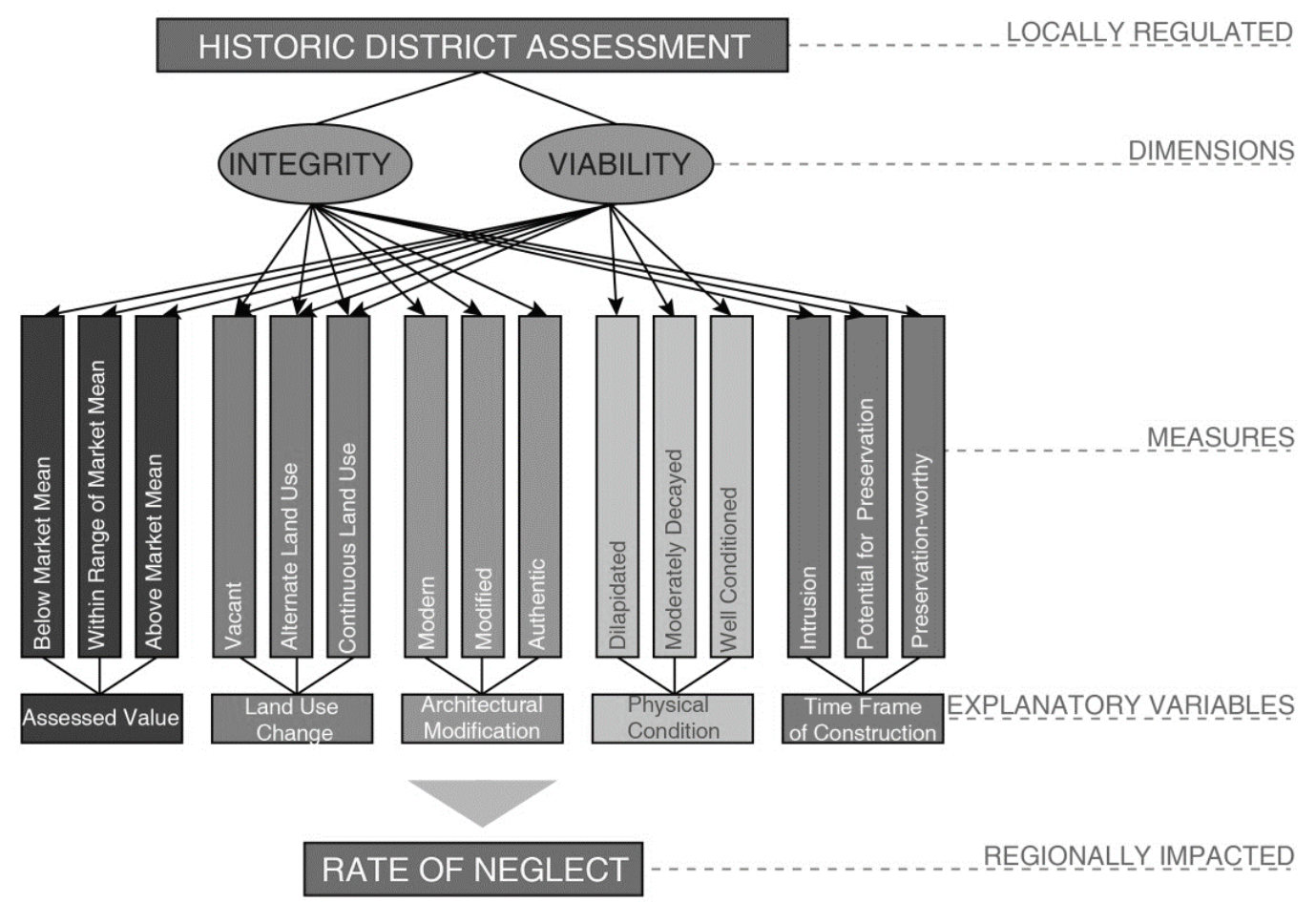

Figure 1. Newman's Model of Measuring Neglect.

After individual building totals were mapped as point values, the cross-case comparison used GIS analyses to identify and map larger-scaled areas of the built environment which were neglected. Hot spot analysis was performed for each spatially located variable and an IDW was performed from the hot spot analysis. Each hot spot analysis map was then overlaid using suitability modeling which was weighted to identify both neglected and viable spaces. 


\section{Findings}

\subsection{Inventory of Conditions}

Each borough under investigation displayed analogous patterns during the building-scaled inventory (Table 2). The largest percentage of buildings built from 1971 to present was occupied by Doylestown (60\%), but a large proportion of these buildings were also vacant (69\%). Over onehalf of the sampled buildings were provided new land uses through adaptive reuse (60\%); simultaneously Doylestown has a large proportion of its buildings in good condition (86\%). Quakertown had a large percentage of its buildings erected from 1940 to 1970 (36\%) and also show a large degree of vacancy $(64 \%)$. Relatedly, a large proportion of its built environment was also experiencing dilapidation (74\%). The assessed value of structures with occupants was generally above market average (47\%). Bristol, has the lowest proportion of newly erected buildings (44\%) but the highest vacancy percentage $(80 \%)$. While $65 \%$ were renovated, $67 \%$ were considered dilapidated. Bristol, on the other hand, had a relatively high amount of buildings above market mean value (93\%). The lowest proportion of buildings that were neglected belonged to Doylestown (1.5\%),
Quakertown had $3.1 \%$ of its buildings neglected and Bristol had $9.1 \%$ (Table 3). The portion of transitory structures were all extremely similar across boroughs while Bristol had a low proportion of buildings that were viable $(9.1 \%$.)

\subsection{Correlational Results}

We performed polychoric correlation analyses for ordinal variables to measure the relationship between the five variables (Table 4). We notice an interesting result - the variables show positive and negative correlations. Specifically, land use change and building condition are negatively correlated with time frame of construction and architectural modification. This result is intuitive when we consider how the variables are measured. For example, this result means that newer buildings are more likely to have continuous land use and be well-composed. The only statistically significant correlations are between architectural medication and time frame of construction (0.697)-indicating that buildings that are modern are more likely to be newer buildings-and architectural modification and land use change (-0.094)-indicating buildings that are modern structures are more likely to have continuous land use.

Table 2. Inventory of measures accepted for structures sampled per town.

\begin{tabular}{|c|c|c|c|c|c|c|c|c|c|}
\hline & & \multicolumn{2}{|c|}{ Doylestown } & \multicolumn{2}{|c|}{ Quakertown } & \multicolumn{2}{|l|}{ Bristol } & \multicolumn{2}{|c|}{ Overall } \\
\hline & & Count & Rate & Count & Rate & Count & Rate & Count & Rate \\
\hline \multicolumn{2}{|c|}{ Time Frame of al = 1971-present } & 12 & 0.185 & 17 & 0.258 & 11 & 0.200 & 40 & 0.215 \\
\hline \multirow[t]{3}{*}{ Construction } & $a 2=1941-1970$ & 14 & 0.215 & 17 & 0.257 & 20 & 0.364 & 51 & 0.274 \\
\hline & $a 3=1900-1940$ & 39 & 0.60 & 32 & 0.485 & 24 & 0.436 & 95 & 0.511 \\
\hline & Total & 65 & 1 & 66 & 1 & 55 & 1 & 186 & 1 \\
\hline \multirow{4}{*}{$\begin{array}{l}\text { Land Use } \\
\text { Change }\end{array}$} & $\mathrm{bl}=$ Vacant & 2 & 0.031 & 7 & 0.106 & 8 & 0.146 & 17 & 0.091 \\
\hline & b2 = Alternate Use & 18 & 0.277 & 17 & 0.258 & 5 & 0.091 & 40 & 0.215 \\
\hline & b3 = Continuous & 45 & 0.692 & 42 & 0.636 & 42 & 0.764 & 129 & 0.69 .4 \\
\hline & Total & 65 & 1 & 66 & 1 & 55 & 1 & 186 & 1 \\
\hline \multirow{4}{*}{$\begin{array}{l}\text { Architectural } \\
\text { Modification }\end{array}$} & $c l=$ Modern & 11 & 0.169 & 15 & 0.227 & 10 & 0.182 & 36 & 0.194 \\
\hline & $c 2=$ Modified & 39 & 0.600 & 43 & 0.652 & 35 & 0.636 & 117 & 0.629 \\
\hline & c3 = Authentic & 15 & 0.231 & 8 & 0.121 & 10 & 0.182 & 33 & 0.177 \\
\hline & Total & 65 & 1 & 66 & 1 & 55 & 1 & 186 & 1 \\
\hline Physical & dl = Dilapidated & 0 & 0 & 1 & 0.015 & 5 & 0.091 & 6 & 0.032 \\
\hline
\end{tabular}




\begin{tabular}{|c|c|c|c|c|c|c|c|c|c|}
\hline \multirow{4}{*}{ Condition } & d2 = Moderate & 8 & 0.123 & 13 & 0.197 & 14 & 0.255 & 35 & 0.188 \\
\hline & $\begin{array}{l}\text { d3 }= \\
\text { Composed }\end{array}$ & Nell 57 & 0.877 & 52 & 0.788 & 36 & 0.655 & 145 & 0.780 \\
\hline & Total & 65 & 1 & 66 & 1 & 55 & 1 & 186 & 1 \\
\hline & $e 1=\$ 0-81,000$ & 52 & 0.800 & 31 & 0.470 & 51 & 0.927 & 134 & 0.720 \\
\hline \multirow[t]{3}{*}{$\begin{array}{l}\text { Assessed } \\
\text { Value }\end{array}$} & $\begin{array}{l}\mathrm{e} 2=\$ 82,000 \\
162,000\end{array}$ & -9 & 0.139 & 25 & 0.379 & 1 & 0.018 & 35 & 0.188 \\
\hline & $\begin{array}{l}\mathrm{e} 3=\$ 163,000 \\
243,000\end{array}$ & 4 & 0.061 & 10 & 0.151 & 3 & 0.055 & 17 & 0.092 \\
\hline & Total & 65 & 1 & 66 & 1 & 55 & 1 & 186 & 1 \\
\hline
\end{tabular}

Table 3. Neglected and viable structures per town.

\begin{tabular}{lllllll}
\hline & \multicolumn{2}{l}{ Doylestown } & \multicolumn{2}{l}{ Quakertown } & \multicolumn{2}{l}{ Bristol } \\
\cline { 2 - 7 } & $\mathbf{n}$ & $\mathbf{\%}$ & $\mathbf{n}$ & $\mathbf{\%}$ & $\mathbf{n}$ & $\mathbf{\%}$ \\
\hline Neglected (5-8) & 1 & 1.5 & 2 & 3.1 & 5 & 9.1 \\
Transitory (9-12) & 52 & 80 & 51 & 78.5 & 45 & 81.8 \\
Viable (13-15) & 12 & 18.5 & 12 & 18.5 & 5 & 9.1 \\
\hline
\end{tabular}

Table 4. Polychoric Correlation Analysis Output.

\begin{tabular}{|c|c|c|c|c|c|}
\hline & & $\begin{array}{l}\text { Land Use } \\
\text { Change }\end{array}$ & $\begin{array}{l}\text { Architectural } \\
\text { Modification }\end{array}$ & $\begin{array}{l}\text { Building } \\
\text { Condition }\end{array}$ & $\begin{array}{l}\text { Assessed } \\
\text { Value }\end{array}$ \\
\hline Time Frame of & Polychoric Correlation & -0.016 & $0.697 * *$ & -0.014 & 0.126 \\
\hline Construction & Sig. (2-tailed) & 0.065 & 0.000 & 0.110 & 0.792 \\
\hline Land Use & Polychoric Correlation & 1 & $-0.094^{* *}$ & 0.241 & -0.248 \\
\hline Change & Sig. (2-tailed) & & 0.000 & 0.019 & 0.969 \\
\hline Architectural & Polychoric Correlation & & 1 & -0.211 & -0.047 \\
\hline Modification & Sig. (2-tailed) & & & 0.592 & 0.383 \\
\hline Building & Polychoric Correlation & & & 1 & -0.026 \\
\hline Condition & Sig. (2-tailed) & & & & 0.750 \\
\hline
\end{tabular}

${ }^{* *} \mathrm{a}<0.01 ;{ }^{*} \mathrm{a}<0.05$

Table 5. Explanation of Variances.

\begin{tabular}{llll}
\hline Measure & Eigenvalue & Variance Explained & $\begin{array}{l}\text { Cumulative } \\
\text { Explained }\end{array}$ \\
\hline 1 & 1.77 & 0.354 & 0.354 \\
2 & 1.3 & 0.259 & 0.614 \\
3 & 1.01 & 0.203 & 0.817 \\
\hline
\end{tabular}

To understand how these five variables can be combined into, we ran polychoric principle component analysis. In Table 5, we notice that the selected variables explain three underlying aspects of neglect with Eigenvalues above 1 for three factors. These three factors together explain over 80 percent of the variance in the neglect scores among units. As expected from the correlation matrix, the variables Time Frame of
Construction and Architectural Modification indicate one similar factor of neglect and load on the first factor. The other three variables, Land Use Change, Building Condition, and Assessed Value, load onto both factors 2 and 3 .

Because all five variables relate to our conceptual understanding of neglect and the lack of one clear factor, we choose to combine them into one rate of neglect. There are various 
methods to create a combined index score, including weighting variables based on the correlation matrix or polychoric factor analysis results. Because of the limited ordinal scaling of the variables (i.e., only values of 1,2 , and 3 ) and the smaller sample size $(n=186)$, we are concerned about strongly interpreting these results. Thus, we chose simplicity in this exploratory analysis of neglect rating and sum the scores of the five variables. We reverse code timeframe of construction and architectural modification because of their negative correlations with the other variables. The scores could range from 5 (a building scored 1 on every variable) to 15 (a building scored 3 on every variable). Overall, our actual rate of neglect scores range from 6 to 15 , with a mean of 11 and standard deviation of 1.61. In Table 6, we show the rates of average neglect for each town. All three towns have similar rates of neglect, but Bristol shows the highest rates with an average score per structure of 10.55. Only 1 building in our study scored the maximum of 15 , and it is in Doylestown (Table 6).

Table 6. Output of IDW and Neglect Rate Comparisons.

\begin{tabular}{|c|c|c|c|c|}
\hline \multicolumn{2}{|c|}{ Output of IDW and Neglect Rates } & \multirow[t]{2}{*}{ Doylestown } & \multirow[t]{2}{*}{ Quakertown } & \multirow[t]{2}{*}{ Bristol } \\
\hline Neglected (Black) & $(<-2.58)$ & & & \\
\hline & $(-2.58-1.96)$ & $22.21 \%$ & $18.37 \%$ & $37.58 \%$ \\
\hline & $(-1.96-1.65)$ & & & \\
\hline \multirow{4}{*}{$\begin{array}{l}\text { Grey (Transitory) } \\
\text { Viable (White) }\end{array}$} & $(-1.65-1.65)$ & $29.41 \%$ & $57.45 \%$ & $60.20 \%$ \\
\hline & $(1.65-1.96)$ & & & \\
\hline & $(1.96-2.58)$ & $48.38 \%$ & $24.18 \%$ & $2.22 \%$ \\
\hline & $(>2.58)$ & & & \\
\hline \multicolumn{2}{|l|}{ Range } & $15-8$ & $14-8$ & $13-7$ \\
\hline \multicolumn{2}{|c|}{$\begin{array}{l}\text { Mean per Structure (SD) } \\
\text { Total Score/Sample Size }\end{array}$} & $11.28(1.57)$ & $11.11(1.54)$ & $10.55(1.68)$ \\
\hline \multicolumn{2}{|c|}{$\begin{array}{l}\text { Rate of Avg. Neglect } \\
\text { (Mean/15)-100\% }\end{array}$} & $24.80 \%$ & $25.90 \%$ & $29.70 \%$ \\
\hline
\end{tabular}

\subsection{Cross-Case GIS Analysis}

Each building surveyed was geocoded using its address, new fields were created as attributes using the data obtained, maps were created according the attributed developed, and then Hotspot and IDW tools were applied. High zscores, hot spots, designated areas which with clustered neglect. The IDW combined points created from each building surveyed and suitability models were then run with equal weighting. The suitability maps read where darker areas represent and lighter areas are less neglected (Figure 2, 3, and 4). Doylestown has nearly one half of its area as viable and a very low proportion of neglected area $(48.38 \%$ and 22.21\%, respectively) (Table 6). Quakertown has nearly one quarter of its space as viable and nearly one fifth neglected $24.18 \%$ and $18.37 \%$, respectively) and Bristol has relatively no viable space and over one third of its area neglected (2.22\% and $37.58 \%$, respectively) (Table 6). 


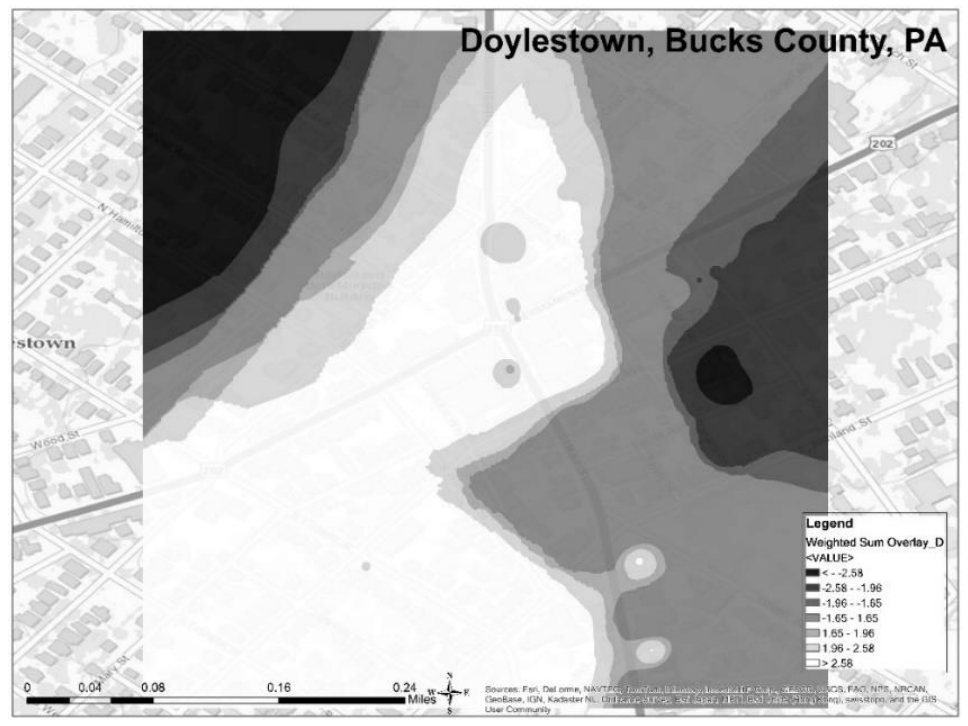

Figure 2. Doylestown Hot Spot Analysis.

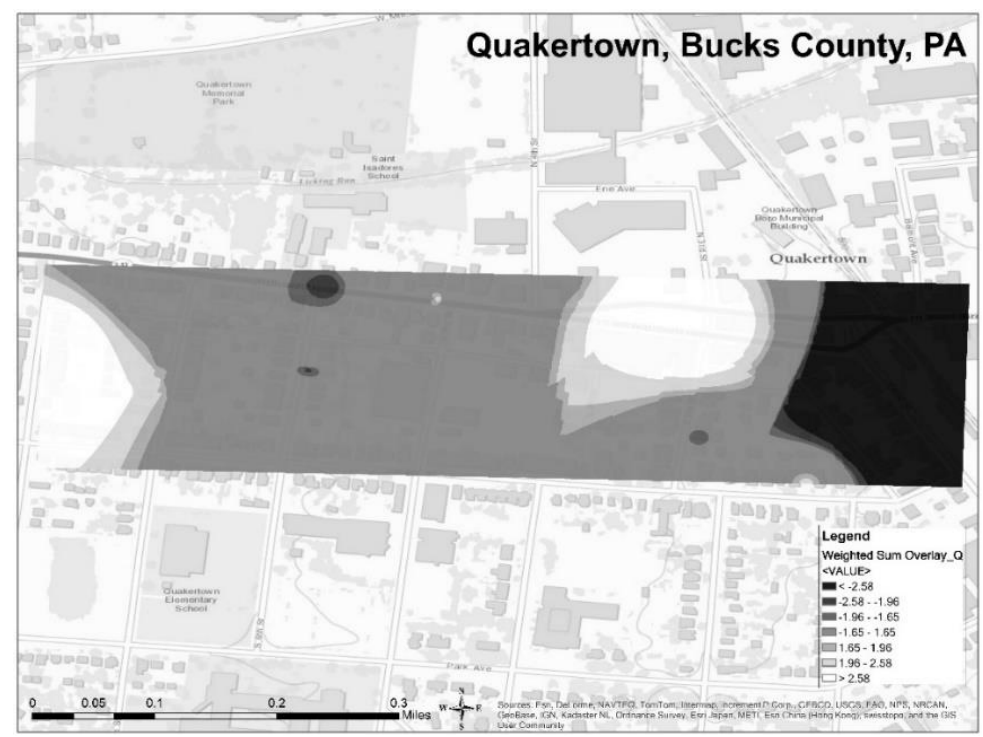

Figure3. Quakertown Hot Spot Analysis.

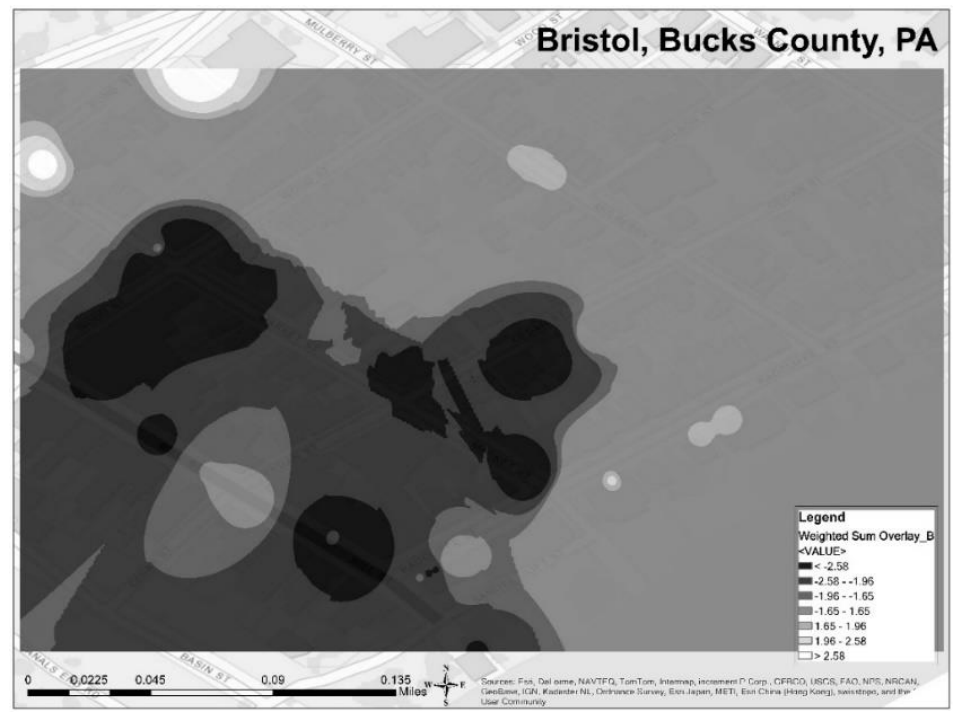

Figure 4. Bristol Hot Spot Analysis. 


\section{Conclusions and Outlook}

This research sought to determine if external land use management could help deter the process of demolition by neglect in the historic built environment, specifically focusing on the alteration of viability rates and the characteristics of neglect as land preservation increased or decreased. Results indicate as amounts of peripheral preserved land increased, viable areas increase while rates of neglect decreased. As fringe farmland preserves increased by city, the overall ratio of viable structures increased, the amount of individual neglected structures structures had changed over time in an effort to keep them viable. However, each borough also displayed a high proportion of vacancies, with Bristol experiencing the highest. The relationship of timeframe of construction and architectural modification indicates if historic structures are present, modification of the area's structural integrity may be necessary to keep it vital through time. This presents preservationists with a tough predicament- a battle between integrity and viability.

Historic buildings and vacancy rates were relatively high across all cases. Also, while amount of retained historic buildings was larger as amount of farmland preserves increased, changes in function per retained building were also quite high, suggesting that if a town is to retain heritage structures, adaptive reuse could be a key factor in decreasing the neglect of these retained structures while contributing to their viability. This condition suggests that that while external land use management can help contain cities to retain historic buildings, population stability and land use consistency cannot be soundly proclaimed to be heavily affected.

For these reasons, it cannot be soundly stated that external land preservation has a direct influence on increasing viability in historic areas. However, exogenous approaches to managing the historic built environment are a necessary to deter the process of neglect, but need to be implemented as part of a multi-combinational approach involving adaptive reuse and land use and incentive policies. Studies linking heritage preservation to broader regional land use strategies need to be continually explored, and decreased, the rate of average neglect decreased, but the overall proportion of the area of the built environment in need of immediate regeneration was not necessarily smaller.

This suggests that external land use management strategies can have an indirect effect on neglect rates in historic areas. Hot Spot Analyses supported the hypothesis - as amount of agricultural preservation increased, there was an increase in viability. While all three towns had high ratios of historic structures, many of the land uses in

these

the current paradigm shift should be accepted as a pliable avenue of examination. Local preservation policies need to begin to determine which broad-scale practices fit best into their smaller scale preservation efforts to produce a multi-combinational/multi-scalar approach.

\section{Acknowledgments}

This research did not receive any specific grant from funding agencies in the public, commercial, or non-for-profit sectors.

\section{References}

Alberts, H. C., \&Brinda, M. R. (2005). Changing approaches to historic preservation in Quedlinburg, Germany. Urban Affairs Review, 40(3),

390-401.

https://doi.org/10.1177/1078087404267618

Alderson, C. R. (2006). Responding to context: Changing perspectives on appropriate change in historic settings. APT Bulletin, 37(4), 22-33. Available

at: https://www.getty.edu/conservation/publication s resources/pdf_publications/pdf/cahe_bibliogr aphy.pdf

Avrami, E. C. (2012). A systems approach to historic preservation in an era of sustainability planning. Rutgers University-Graduate SchoolNew Brunswick. https://rucore.libraries.rutgers.edu/rutgerslib/375221

Ben-Hamouche, M. (2013). The paradox of urban preservation: Balancing permanence and changeability in old Muslim cities. Journal of Urbanism: International Research on Placemaking and Urban Sustainability, 6(2), 192- 
212.

https://doi.org/10.1080/17549175.2013.820213

Bourke, L., Jacob, S., \&Luloff, A. (1996). Response to Pennsylvania's agricultural preservation Programs. Rural sociology, 61(4), 606-629. https://doi.org/10.1111/j.1549$0831.1996 . t b 00636 . x$

Box, P. (2003). Safeguarding the plain of jars: Megaliths and unexploded ordnance in the Lao People's Democratic Republic. Journal of GIS in Archaeology, 1, 90-102. Available at: https://www.researchgate.net/publication/2640 48630 Safeguarding the Plain_of_Jars megaliths _and_unexploded_ordnance_in the_Lao_Peopl e\%27s_Democratic_Republic

Burrough, P. A., \& McDonnell, R. A. (1988). Principles of geographical information systems: Oxford University Press. Available at: https://pdfs.semanticscholar.org/d8e0/b6b225b 36cac23608b41a51e13ddb2746cbd.pdf

Cano, M., Garzon, E., \& Sanchez-Soto, P. (2013). Historic preservation, GIS, \& rural development: The case of Almería province, Spain. Applied Geography, 42, 34-47. https://doi.org/10.1016/j.apgeog.2013.04.014

Cassar, M. (2009). Sustainable heritage: challenges and strategies for the twenty-first century, APT Bulletin. Journal of Preservation Technology, 40(1), 3-11. Available at: http://discovery.ucl.ac.uk/18790/1/18790.pdf

Collins, R. C., Waters, E. B., \& Dotson, A. B. (1991). America's downtowns: Growth, politics and preservation. In Politics and Preservation. Washington, D.C: The Preservation Press. https://www.amazon.com/Americas-

Downtowns-Growth-Politics-

Preservation/dp/0471144991

Cook, R. E. (1996). Is landscape preservation an oxymoron. Paper presented at the George Wright Forum.

http://www.georgewright.org/131cook.pdf

Doneus, M. (2001). Precision mapping and interpretation of oblique aerial photographs. Archaeological Prospection, 8(1), 13-27. https://doi.org/10.1002/1099-

0763(200103)8:1<13::aid-arp158>3.0.co;2-\#

Doratli, N. (2005). Revitalizing historic urban quarters: A model for determining the most relevant strategic approach. European Planning
Studies,

$13(5)$

$749-772$.

https://doi.org/10.1080/09654310500139558

Forrester, J. W. (1969). Urban dynamics. Cambridge, MA: MIT Press. http://science.sciencemag.org/content/168/393 2/693

Guillot, D., \& Leroy, G. (1995). The use of GIS for archaeological resource management in France: The SCALA Project, with a case-study in Picardie. London: Taylor and Francis. https://books.google.com.tr/books?id=ZPTLjMLSc $=$

$\underline{\text { UC \&pg }}=P A 15 \& \mid \mathrm{pg}=P A 15 \& d q=T h e+$ use + of $+\mathrm{GIS}+\mathrm{f}$ or+archaeological+resource+management+in+F rance:+The+SCALA+Project,+with+a+case$\underline{\text { study+in+Picardie \&source=bl\&ots=ivPcYEljiO\&sig }}$ =-

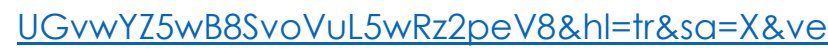
$\underline{d=2 a h U K E w i t 2-}$

rprazfAhXFmlsKHWnYBioQ6AEwAXoECAgQAQ\#v =onepage \& $\mathrm{q} \& \mathrm{f}=$ false

Hylton, T. (1995). Save our land, save our towns: a plan for Pennsylvania: Rb Books. http://www.bullfrogfilms.com/guides/saveguide. pdf

Jackson, J. B. (1997). Landscape in sight: looking at America: Yale Univrsity Press. https://yalebooks.yale.edu/book/9780300071160 /landscape-sight

Jigyasu, R. (2002). Monuments and sites in their setting: Conserving cultural heritage in changing townscapes and landscapes. Paper presented at the International Centre for the Study of the Preservation and Restoration of Cultural Property (ICCROM) Symposium, India. http://openarchive.icomos.org/387/

Kaimaris, D., Sylaiou, S., Georgoula, O., \&Patias, P. (2011). GIS of landmarks management. Journal of Cultural Heritage, 12(1), 65-73. https://doi.org/10.1016/j.culher.2010.09.001

King, L. J. (1984). Central Place Theory. In. Beverly Hills, CA: Sage Publications. http://onlinebooks.library.upenn.edu/webbin/bo ok/lookupid? key=olbp64142

Kvamme, K. L. (1993). Spatial statistics and GIS: An integrated approach. Aarhus: Aarhus University Press. $\quad$ http://dx.doi.org/10.15496/publikation$\underline{2569}$ 
Leatherbarrow, D., \&Mostafavi, M. (1993). On weathering: The life of buildings in time. Cambridge, MA: MIT Press. https://www.amazon.co.uk/Weathering-LifeBuildings-Time-Press/dp/026263144X

Limp, W. F. (1999). Geographic information systems in historic preservation. Archives and Museum Informatics, 325-340. https://doi.org/10.1007/978-1-4615-4145-5 10

Listokin, D. (1997). Growth management and historic preservation: Best practices for synthesis. The Urban Lawyer, 199-213. https://www.jstor.org/stable/27895057? seq=1 \#m etadata_info_tab_contents

Listokin, D., Listokin, B., \& Lahr, M. (1998). The contributions of historic preservation to housing and economic development. Housing policy debate, 9 (3) 431-478. https://doi.org/10.1080/10511482.1998.9521303

Montello, D., \& Sutton, P. (2006). An introduction to scientific research methods in geography. Thousand Oaks, CA: Sage Publications. http://dx.doi.org/10.4135/9781452225814

Murray, D. M. (1995). The management of archaeological information-A strategy. BAR INTERNATIONAL SERIES, 598, 83-83. https://proceedings.caaconference.org/files/19 93/12 Murray_CAA 1993.pdf

National Trust for Historic Preservation. (2008). Teardown resource guide: Teardowns by state and community. Retrieved from http://www.preservationnation.org/teardowns

Newman, G. D. (2013). A conceptual model for measuring neglect in historic districts. Journal of Preservation, Education, and Research(6), 41-58. https://www.researchgate.net/publication/2651 24614_A_Conceptual_Model_for_Measuring_Ne glect in Historic Districts

Newman, G. D. (2015). The eidos of urban form: a framework for heritage-based place making. Journal of Urbanism: International Research on Placemaking and Urban Sustainability, 1-20. https://doi.org/10.1080/17549175.2015.1070367

Newman, G. D., \&Saginor, J. (2014). Four Imperatives for Preventing Demolition by Neglect. Journal of Urban Design, 19(5), 622-637. https://doi.org/10.1080/13574809.2014.943705

Nijkamp, P. (1991). Evaluation measurement in conservation planning. Journal of Cultural
Economics,

15(1),

$1-27$.

https://link.springer.com/article/10.1007\%2FBF022 $\underline{67399}$

Olson, R. K., \&Lyson, T. A. (1999). Under the blade: The conversion of agricultural landscapes. Boulder, CO: Westview Press. https://www.amazon.com/Under-Blade-

Conversion-Agricultural-

Landscapes/dp/0813335973

Pickerill, T., \& Armitage, L. (2009). The management of built heritage: A comparative review of policies and practice in Western Europe, North America and Australia. Paper presented at the Pacific Rim Real Estate Society - 15th Annual Conference, University of Technology Sydney. https://arrow.dit.ie/cgi/viewcontent.cgi? article= $1036 \&$ context=beschreccon

Pickerill, T., \& Pickard, R. (2007). A review of fiscal measures to benefit heritage conservation. RICS Research Paper Series, 7(6). https://arrow.dit.ie/beschrecart/11/

Roorda, I. M., \&Wiemer, R. (1992). Towards a new archaeological information system in the Netherlands. In G. R. Lock \& J. Moffett (Eds.), Computer applications and quantitative methods in archaeology (pp. 85-88). Oxford: Tempus reparatum. https://proceedings.caaconference.org/paper/ 11 roorda_wiemer_caa_1991/

Treib, M. (2008). Review of Drosscape: Wasting land in urban America by Alan Berger. Landscape Journal, 27(1), 154-155. https://www.amazon.com/Drosscape-WastingLand-Urban-America/dp/1568987137

U.S. Department of Agriculture. (2005). Urban ecosystem analysis of the delaware river valley: Calculating the value of nature. Washington, DC: American Forests.

http://www.wrc.udel.edu/wpcontent/uploads/2016/07/EconomicValueofNat ureandEcosystemsintheDelawareRiverBasin2016. pdf

Yahner, T. G., \&Nadenicek, D. J. (1997). Community by design: Contemporary problems-historic resolve. Landscape and Urban Planning, 39(2), 137-151. https://doi.org/10.1016/S0169-2046(97)00051-0 